Annals of Plant and Soil Research 23(3): 286-290 (2021)

https://doi.org/10.47815/apsr.2021.10071

\title{
Foliar application of micronutrients enhances growth, yield and quality of strawberry (Fragaria $\times$ ananassa Duch.)
}

\author{
B.M. PARMAR, B.M. TANDEL, B. CHAKRABORTY ${ }^{1 *}$, M. SARKAR ${ }^{2}$ AND S. RATHOD \\ Department of Fruit Science, ASPEE College of Horticulture and Forestry, Navsari Agricultural University, \\ Navsari-396 450, Gujarat, India \\ Received: March, 2021: Revised accepted: April, 2021
}

\begin{abstract}
The investigation was carried out At Navsari Agricultural University, Waghai during 2018-19 to evaluate the effect of foliar application of $\mathrm{Zn}$ and $\mathrm{Fe}$ on growth, yield and quality of strawberry (Fragaria $x$ ananassa Duch.) $\mathrm{Cv}$. Winter Dawn. The $\mathrm{ZnSO}_{4}, 7 \mathrm{H}_{2} \mathrm{O}$ and $\mathrm{FeSO}_{4}, 7 \mathrm{H}_{2} \mathrm{O}$ were used as a source for $\mathrm{Zn}$ and Fe, respectively and applied as foliar sprays individually $(0.2 \%$ and $0.4 \%)$ as well as in combination to the strawberry plants at 30, 60 and 75 days after planting of uniform runners. The plants which received no spraying were treated as control. The results indicated that foliar spraying of $0.4 \% \mathrm{ZnSO}_{4}, 7 \mathrm{H}_{2} \mathrm{O}+0.2 \% \mathrm{FeSO}_{4}, 7 \mathrm{H}_{2} \mathrm{O}$ significantly increased the plant spread, number of leaves, number of crowns, leaf area, length of petiole, number of runners, number of flowers, number of fruits, fruit weight, marketable fruit percentage, marketable and total fruit yield over control plants. However, fruits with significantly the highest total soluble solid, acidity and anthocyanin content were recorded with the foliar application of $0.4 \% \mathrm{ZnSO}_{4}, 7 \mathrm{H}_{2} \mathrm{O}+0.4 \% \mathrm{FeSO}_{4}, 7 \mathrm{H}_{2} \mathrm{O}$. However, the micronutrient treatments failed to influence any significant effect on days taken to $50.0 \%$ flowering, fruit firmness and acidity content of the strawberry fruits. All the parameters were recorded minimum in plants which received no spraying.
\end{abstract}

Key words: Micronutrient, foliar application, Zn, Fe, Strawberry

\section{INTRODUCTION}

Strawberry (Fragaria $x$ ananassaDuch.) is the most attractive and delicious fruit of the family Rosaceae. The juicy pulp of this fruit containshigh amount of vitamin $\mathrm{A}, \mathrm{C}$ and minerals like $\mathrm{Fe}$ and $\mathrm{K}$. This fruit can be consumed as fresh and after processing. Pectin present in the fruit pulp makes this fruit highly suitable for preparation of jams and jellies. The natural antioxidants in the strawberry fruit also help to reduce the oxidative stresses. This fruit is also found to be beneficial in reduction of inflammation and obesity related disorders and prevention of several types of cancers and heart related diseases (Afrin et al., 2016). Hence, strawberry offers several preventive and therapeutic health benefits and falls under the category of functional food (Basu et al., 2014).For these reasons, the cultivation of this fruit crop is expanding from temperate and subtropical to tropical zones including the southern hilly parts of Gujarat (Rathod et al., 2021).It is one of the most sensitive fruit crops to nutrient management and optimum supply of both macro and micronutrients could improve both the aspects of yield and quality. Apart from macronutrients, the micronutrients also play a vital role in plant growth and developmental processes. Micronutrients are actively involved in plant metabolism process like respiration, photosynthesis, synthesis of chlorophylls and numerous enzymatic activities. Zinc (Zn) plays a vital role in carbohydrate metabolism, promotes the formation of starch and loading of photo assimilates to fruits. On the other hand, iron $(\mathrm{Fe})$ is reported to be a key element of several enzymes involving in electron transport redox reactions and $\mathrm{Fe}-\mathrm{S}$ proteins. Being also a component of non-heme iron proteins, it also regulates the vital physiological processes of plants like photosynthesis and respiration. Further, several strategies are available to supply micronutrients to the plants and foliar fertilization of micronutrients appears to be more effective than soil applications. Improvements in terms of both yield and quality with the use of $\mathrm{Zn}$ and $\mathrm{Fe}$ have been reported in several fruit crops (Shanker et al., 2019). However, reports on investigation of foliar application of $\mathrm{Zn}$ and $\mathrm{Fe}$ in strawberries, more particularly in hills of southern Gujarat, in order to improve the quality and yield are meagre. Hence, the present investigation had been undertaken to study the effect of foliar fertilization of $\mathrm{Zn}$ and $\mathrm{Fe}$ in strawberry cv. Winter Dawn.

\footnotetext{
${ }^{7}$ Regional Research Station (Terai Zone), Uttar Banga Krishi Viswavidyalaya, Pundibari, Coochbehar, West Bengal

${ }^{2}$ Department of Horticulture, College of Agriculture, Navsari Agricultural University, Waghai, The Dangs, Gujarat

*Email of the corresponding author: binayak.hort@gmail.com; binayak@ubkv.ac.in
} 


\section{MATERIALS AND METHODS}

The experiment was carried out at Rambhas Farm located $20^{\circ} 77^{\prime} \mathrm{N}$ and $73^{\circ} 50^{\prime}$ E, Hill Millet Research Station, Navsari Agricultural University, Waghai, India during the year 2018-19. The soil of the experimental site was sandy loam and neutral in reaction with $\mathrm{pH}$ 6.6. The available $\mathrm{N}, \mathrm{P}$ and $\mathrm{K}$ of the experimental field before the commencement of the experiment were 312,60 and $230 \mathrm{~kg} \mathrm{ha}$ ${ }^{1}$, respectively with $11.8 \%$ organic $\mathrm{C}$. The field was fertilized with the recommended dose of FYM (10 t ha $\left.{ }^{-1}\right)$ and fertilizers $120 \mathrm{~kg} \mathrm{~N}+80$ $\mathrm{kg} \mathrm{P}+100 \mathrm{~kg} \mathrm{~K} \mathrm{ha}^{-1}$ as Urea, SSP and MOP, respectively. All these fertilizers were applied at the time of field preparation. Healthy, almost uniform, well developed, disease and pest-free runner plantlets of strawberry cv. Winter Dawn were planted at second week of October at a spacing of $60 \mathrm{~cm} \times 30 \mathrm{~cm}$. Paddy straw was used as mulching material. Each experimental bed $(3 \mathrm{~m} \times 1.8 \mathrm{~m})$ consisted of 30 plants with 12 plants in a net plot area $(1.8 \mathrm{~m} \times 1.2 \mathrm{~m})$. Foliar spraying of micronutrients $(\mathrm{Zn}$ and $\mathrm{Fe})$ was carried out thrice at 45,60 and 75 days after planting. The experiment was laid out in randomized block design (RBD) with nine treatments viz. $\mathrm{T}_{1}: 0.2 \% \mathrm{ZnSO}_{4}, 7 \mathrm{H}_{2} \mathrm{O}, \mathrm{T}_{2}: 0.4$ $\% \mathrm{ZnSO}_{4}, 7 \mathrm{H}_{2} \mathrm{O}, \mathrm{T}_{3}: 0.2 \% \mathrm{FeSO}_{4}, 7 \mathrm{H}_{2} \mathrm{O}, \mathrm{T}_{4}$ : $0.4 \% \mathrm{FeSO}_{4}, 7 \mathrm{H}_{2} \mathrm{O}, \mathrm{T}_{5}: 0.2 \% \mathrm{ZnSO}_{4}, 7 \mathrm{H}_{2} \mathrm{O}+$ $0.2 \% \mathrm{FeSO}_{4}, 7 \mathrm{H}_{2} \mathrm{O}, \mathrm{T}_{6}: 0.2 \% \mathrm{ZnSO}_{4}, 7 \mathrm{H}_{2} \mathrm{O}+$ $0.4 \% \mathrm{FeSO}_{4}, 7 \mathrm{H}_{2} \mathrm{O}, \mathrm{T}_{7}: 0.4 \% \mathrm{ZnSO}_{4}, 7 \mathrm{H}_{2} \mathrm{O}+$ $0.2 \% \mathrm{FeSO}_{4}, 7 \mathrm{H}_{2} \mathrm{O}, \mathrm{T}_{8}: 0.4 \% \mathrm{ZnSO}_{4}, 7 \mathrm{H}_{2} \mathrm{O}+$ $0.4 \% \mathrm{FeSO}_{4}, 7 \mathrm{H}_{2} \mathrm{O}, \mathrm{T}_{9}$ : no spray (control) and replicated thrice.

The leaf area of strawberry was measured using leaf area meter (Biovis PSML2000). The fruit firmness and total soluble solid (TSS) content of strawberry fruit were determined using digital fruit firmness tester (LTLUTRON-FR-5120) and digital refracto meter (ATAGO Pocket 3810, PAL-1), respectively. The harvested fruits under each treatment were categorised in marketable and non-marketable fruits (fruits having weight $<10 \mathrm{~g}$ or malformed (Misshapen) or disease infected). The titratable acidity, ascorbic acid and sugar content of fruits were determined following the standard procedures (AOAC, 1980). The anthocyanin content of the strawberry fruits was determined following the method described by Srivastava and Kumar (2001).The data were analysed for the variance and least significant differences (LSD) were calculated to compare significant effects at $p \leq 0.05$ (Snedecor and Cochran, 1967).

\section{RESULTS AND DISCUSSION}

\section{Growth and flowering of strawberry plant}

The plant growth in terms of plant spread $(26.8 \mathrm{~cm})$ was noted maximum in the plants which received foliar spraying of $0.4 \%$ $\mathrm{ZnSO}_{4}, 7 \mathrm{H}_{2} \mathrm{O}$ and $0.2 \% \mathrm{FeSO}_{4}, 7 \mathrm{H}_{2} \mathrm{O}$ (Table 1). The leaf with larger leaf lamina $\left(126.5 \mathrm{~cm}^{2}\right)$ and maximum length of petiole $(11.1 \mathrm{~cm})$ were also recorded from the same plants. The foliar application of $\mathrm{ZnSO}_{4} .7 \mathrm{H}_{2} \mathrm{O} \quad(0.4 \%)$ and $\mathrm{FeSO}_{4}, 7 \mathrm{H}_{2} \mathrm{O}(0.2 \%)$ had also found to be the best for producing the highest number of leaves (26.3), crowns (3.07) and runners (4.00) in strawberry. All the above parameters were recorded minimum in plants which received no spraying (control plants). The foliar application of $0.4 \% \mathrm{ZnSO}_{4}, 7 \mathrm{H}_{2} \mathrm{O}$ and $0.2 \% \mathrm{FeSO}_{4}, 7 \mathrm{H}_{2} \mathrm{O}$ had resulted $26.9 \%, 36.4 \%$ and $14.7 \%$ increase in plant spread, number of leaves and flowers plant $^{-1}$, respectively over the untreated control plants. The foliar application of micronutrients failed to influence any significant effect on days taken to $50 \%$ flowering in strawberry. However, the plants sprayed with0.4 $\% \mathrm{ZnSO}_{4}, 7 \mathrm{H}_{2} \mathrm{O}$ and $0.2 \% \mathrm{FeSO}_{4}, 7 \mathrm{H}_{2} \mathrm{O}$ exhibited earliest flowering (40.7 DAP) with significantly maximum number of flowers (31.3) in strawberry. Plant growth improvement in strawberry with the foliar application of $\mathrm{Zn}+\mathrm{Fe}$ might be linked to the higher production of plant growth promoting substances, ribonucleic acid, photosynthetic etc. The plant growth regulating substances like auxins have a positive role in plant growth and developmental processes, and the biosynthesis of auxins in the plants is reported to be regulated by the presence of $\mathrm{Zn}$. In addition, $\mathrm{Zn}$ also promotes the synthesis of ribonucleic acid and ribosome. Further, addition of $\mathrm{Fe}$ in spray solution might have helped in production of more photo synthates as Fe plays a significant role in chlorophyll synthesis, maintenance of the structure and function of the chloroplast. Thus, both these elements $(\mathrm{Zn}+\mathrm{Fe})$ boosted up the plant growth of strawberry in terms of all the studied parameters which was found to be significantly higher than the sole 
application of either $\mathrm{Zn}$ or $\mathrm{Fe}$, and control. Similar results were also reported by Bakshi et al. (2013). Earliest flowering with maximum number of flowers in $\mathrm{Zn}+\mathrm{Fe}$ treated strawberry plants established the fact that both these elements have an important role in flowering of plants. Singh et al. (2015) also recorded maximum number of flowers with the application of $\mathrm{Zn}$ and $\mathrm{Fe}$ in strawberry $\mathrm{cv}$. Chandler.

Table 1: Effect of foliar application of micronutrients on growth and floweringof strawberry cv. Winter Dawn

\begin{tabular}{|l|c|c|c|c|c|c|c|c|}
\hline Treatments & $\begin{array}{c}\text { Plant } \\
\text { spread } \\
(\mathrm{cm})\end{array}$ & $\begin{array}{c}\text { Leaves } \\
\text { plant }^{-1}\end{array}$ & $\begin{array}{c}\text { Leaf area } \\
\left(\mathrm{cm}^{2}\right)\end{array}$ & $\begin{array}{c}\text { Length of } \\
\text { petiole } \\
(\mathrm{cm})\end{array}$ & $\begin{array}{c}\text { Crown } \\
\text { plant }\end{array}$ & $\begin{array}{c}\text { Runners } \\
\text { plant }\end{array}$ & $\begin{array}{c}\text { Days taken } \\
\text { to } 50.0 \% \\
\text { flowering }\end{array}$ & $\begin{array}{c}\text { Flowers } \\
\text { plant }^{-1}\end{array}$ \\
\hline $\mathrm{T}_{1}: 0.2 \% \mathrm{ZnSO}_{4}, 7 \mathrm{H}_{2} \mathrm{O}$ & 22.5 & 20.2 & 108.8 & 9.7 & 2.13 & 2.73 & 46.0 & 27.4 \\
$\mathrm{~T}_{2}: 0.4 \% \mathrm{ZnSO}_{4}, 7 \mathrm{H}_{2} \mathrm{O}$ & 22.9 & 22.0 & 113.2 & 10.1 & 2.40 & 3.13 & 44.0 & 27.7 \\
$\mathrm{~T}_{3}: 0.2 \% \mathrm{FeSO}_{4}, 7 \mathrm{H}_{2} \mathrm{O}$ & 21.9 & 20.5 & 111.2 & 9.8 & 2.20 & 3.06 & 44.7 & 27.6 \\
$\mathrm{~T}_{4}: 0.4 \% \mathrm{FeSO}_{4}, 7 \mathrm{H}_{2} \mathrm{O}$ & 23.4 & 23.0 & 113.8 & 10.0 & 2.67 & 3.20 & 43.0 & 27.8 \\
$\mathrm{~T}_{5}: \mathrm{T}_{1}+\mathrm{T}_{3}$ & 24.4 & 23.4 & 118.4 & 10.1 & 2.73 & 3.26 & 42.7 & 27.9 \\
$\mathrm{~T}_{6}: \mathrm{T}_{1}+\mathrm{T}_{4}$ & 25.3 & 24.8 & 120.2 & 10.4 & 2.93 & 3.60 & 41.3 & 28.9 \\
$\mathrm{~T}_{7}: \mathrm{T}_{2}+\mathrm{T}_{3}$ & 26.9 & 26.3 & 126.5 & 11.1 & 3.07 & 4.00 & 40.7 & 31.3 \\
$\mathrm{~T}_{8}: \mathrm{T}_{2}+\mathrm{T}_{4}$ & 25.4 & 25.9 & 123.9 & 11.1 & 2.80 & 3.73 & 41.0 & 30.5 \\
$\mathrm{~T}_{9}:$ Control (No spray) & 21.2 & 19.3 & 105.4 & 8.7 & 2.07 & 2.33 & 46.7 & 27.3 \\
$P \leq 0.05$ & 2.09 & 3.76 & 12.95 & 1.04 & 0.56 & 0.22 & $\mathrm{NS}$ & 2.47 \\
\hline
\end{tabular}

\section{Fruiting and yield of strawberry}

The fruits with maximum weight $(14.74$ g) were harvested from the plants receiving foliar spraying of $0.4 \% \quad \mathrm{ZnSO}_{4}, 7 \mathrm{H}_{2} \mathrm{O}$ and $0.2 \% \mathrm{FeSO}_{4}, 7 \mathrm{H}_{2} \mathrm{O}$ (Table 2). The same set of plants also produced maximum number of fruits (19.80) with the highest number of marketable fruits [18.46 (93.3\%)] plant $^{-1}$. This treatment was also found to be the best for producing the highest marketable fruit yield (269.49 $\left.\mathrm{g} \mathrm{plant}^{-1}, 149.71 \mathrm{q} \mathrm{ha}^{-1}\right)$ and total fruit yield $\left(288.91 \mathrm{~g}^{-1}\right.$ plant $\left.^{-1}, 150.79 \mathrm{q} \mathrm{ha}^{-1}\right)$. The lowest number of fruits (total and marketable) plant $^{-1}$ and yield were recorded in the control plants. Similarly, the lowest non-marketable fruit yield (19.43 g plant ${ }^{-1}, 1.07 \mathrm{q} \mathrm{ha}^{-1}$ ) was recorded in the plants which received foliar application of $0.4 \% \mathrm{ZnSO}_{4}, 7 \mathrm{H}_{2} \mathrm{O}$ and $0.2 \%$ $\mathrm{FeSO}_{4}, 7 \mathrm{H}_{2} \mathrm{O}$ [Fig. 1(a) and (b)].
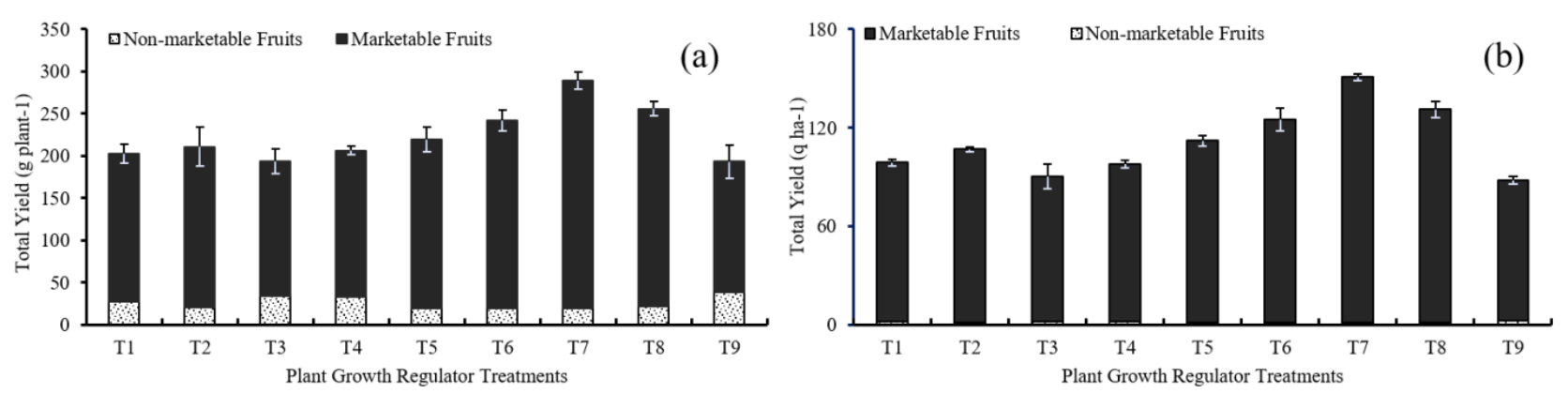

Fig. 1: Effect of foliar application of micronutrients on yield plant ${ }^{-1}$ (a) and yield ha ${ }^{-1}$ (b) of strawberry cv. Winter Dawn

Increase in fruit weight, marketable fruit yield and total yield plant $^{-1}$ with the foliar application of $0.4 \% \mathrm{ZnSO}_{4}, 7 \mathrm{H}_{2} \mathrm{O}$ and 0.2 $\% \mathrm{FeSO}_{4}, 7 \mathrm{H}_{2}$ Owas gained almost $22.1 \%, 74.0$ $\%$ and $49.6 \%$, respectively over the control plants. Being an important component of carbonic anhydrase, $\mathrm{Zn}$ regulated the carbon

metabolism in plant system leading to higher accumulation starch in the developing fruits. Thus, foliar application of $\mathrm{Zn}$ has been found to be beneficial in improving the number and average fruit weight of strawberry. The combined foliar application consisting of both $\mathrm{Zn}$ and $\mathrm{Fe}$ is found to be better than the sole application of these micronutrients for 
improvement of yield and its attributing characters in strawberry. This might be due to addition of beneficial effects of $\mathrm{Fe}$ on yield. Thus, plants receiving $\mathrm{Zn}+\mathrm{Fe}$ might have produced more photo synthates and trans located to the developing fruits and resulting fruits with maximum fruit weight. In addition, foliar application of $\mathrm{Fe}$ at lower concentration was reported to be improved the fruit setting percentage. Significant increase in fruit set and number of flowers with the foliar application of $0.2 \% \mathrm{Fe}$ has been reported in strawberry. The fruit development in strawberry at the early stages is strongly influenced by the extent of auxins translocated from the achenes in the developing fruits. Up regulation of auxin synthesis in plants with the exogenous application of $\mathrm{Zn}$ is well documented. Hence, the strawberry plants treated with both $\mathrm{Zn}+\mathrm{Fe}$ might have synthesized more auxins and also resulting in higher yield through production of more numbers of marketable sized fruits.

Table 2: Effect of foliar application of micronutrients on fruiting of strawberry cv. Winter Dawn

\begin{tabular}{|c|c|c|c|c|c|c|}
\hline Treatments & $\begin{array}{l}\text { Fruit } \\
\text { weight } \\
\text { (g) }\end{array}$ & $\begin{array}{l}\text { Fruit } \\
\text { length } \\
\text { (cm) }\end{array}$ & $\begin{array}{l}\text { Marketable } \\
\text { fruits plant }^{-1}\end{array}$ & $\begin{array}{l}\text { Non-marketable } \\
\text { fruits plant }^{-1}\end{array}$ & $\begin{array}{l}\text { Total fruits } \\
\text { plant }^{-1}\end{array}$ & $\begin{array}{l}\text { Marketable fruit } \\
(\%)\end{array}$ \\
\hline $\mathrm{T}_{1}: 0.2 \% \mathrm{ZnSO}_{4}, 7 \mathrm{H}_{2} \mathrm{O}$ & 12.41 & 3.15 & 14.13 & 2.20 & 16.33 & $86.50(9.33)^{*}$ \\
\hline $\mathrm{T}_{2}: 0.4 \% \mathrm{ZnSO}_{4}, 7 \mathrm{H}_{2} \mathrm{O}$ & 12.70 & 3.29 & 15.00 & 1.60 & 16.60 & $90.42(9.53)$ \\
\hline $\mathrm{T}_{3}: 0.2 \% \mathrm{FeSO}_{4}, 7 \mathrm{H}_{2} \mathrm{O}$ & 12.26 & 3.25 & 13.00 & 2.80 & 15.80 & $82.28(9.10)$ \\
\hline $\mathrm{T}_{4}: 0.4 \% \mathrm{FeSO}_{4}, 7 \mathrm{H}_{2} \mathrm{O}$ & 12.45 & 3.30 & 13.86 & 2.66 & 16.53 & $83.81(9.18)$ \\
\hline$T_{5}: T_{1}+T_{3}$ & 13.16 & 3.41 & 15.20 & 1.46 & 16.66 & $91.22(9.58)$ \\
\hline$T_{6}: T_{1}+T_{4}$ & 13.71 & 3.86 & 16.13 & 1.40 & 17.53 & $92.00(9.62)$ \\
\hline$T_{7}: T_{2}+T_{3}$ & 14.74 & 3.53 & 18.46 & 1.33 & 19.80 & $93.30(9.68)$ \\
\hline$T_{8}: T_{2}+T_{4}$ & 14.10 & 3.50 & 17.13 & 1.53 & 18.66 & $91.80(9.61)$ \\
\hline $\mathrm{T}_{9}$ : Control (No spray) & 12.07 & 3.12 & 12.33 & 3.20 & 15.53 & $79.39(8.94)$ \\
\hline$P \leq 0.05$ & 1.64 & 0.37 & 1.51 & 0.68 & 1.5 & 0.21 \\
\hline
\end{tabular}

${ }^{*}$ Figures in parentheses indicate transformed values

\section{Fruit quality of strawberry}

The fruit firmness and acidity in juice of the strawberry were not influenced by the foliar application of micronutrients (Table 3). However, the plants receiving foliar application of $0.4 \%$ $\mathrm{ZnSO}_{4}, 7 \mathrm{H}_{2} \mathrm{O}$ and $0.4 \% \mathrm{FeSO}_{4}, 7 \mathrm{H}_{2} \mathrm{O}$ (produced the hardiest fruit. The TSS $\left(8.75^{\circ} \mathrm{B}\right)$ and sugar content (total sugar $9.55 \%$ and reducing sugar $5.14 \%$ ) were the maximum in the strawberry fruits produced in the plants receiving foliar application of $0.4 \% \mathrm{ZnSO}_{4}, 7 \mathrm{H}_{2} \mathrm{O}$ and $0.4 \%$ $\mathrm{FeSO}_{4}, 7 \mathrm{H}_{2} \mathrm{O}$. The control plants produced fruits with lowest quality. Fruits with the highest ascorbic acid (94.16 mg $\left.100 \mathrm{~g}^{-1}\right)$ and anthocyanin $\left(41.00 \mathrm{mg} 100 \mathrm{~g}^{-1}\right)$ content were produced in plants treated with0.4\% $\mathrm{ZnSO}_{4}$, $7 \mathrm{H}_{2} \mathrm{O}$ and $0.4 \% \mathrm{FeSO}_{4}, 7 \mathrm{H}_{2} \mathrm{O}$. This treatment increased the ascorbic acid, TSS and total sugar content of strawberry fruits near about $30.8 \%$, $17.0 \%$ and $17.2 \%$, respectively over control plants. The foliar application of both $\mathrm{Zn}+\mathrm{Fe}$ recorded hardiest strawberry fruits with a nonsignificant manner. This is might be due to $\mathrm{Zn}$ induced auxin synthesis leading to hard achene development in strawberry fruits. Further, foliar application of $\mathrm{Fe}$ compounds also increases the fruit firmness and TSS content in peach (Song et al., 2016). Zinc has a role in carbohydrate metabolism by regulating the enzymes responsible for conversion of starch into glucose and leading to fruits with higher TSS, reducing and nonreducing sugar content. Further, foliar $\mathrm{Fe}$ application is reported to increase the TSS and ascorbic acid content. Hence, foliar application of $\mathrm{Zn}+\mathrm{Fe}$ resulted the highest TSS, sugars and ascorbic acid content of the strawberry fruits. Similar findings with the application of $\mathrm{Zn}$ and Fe were also recorded in pomegranate (Mirzapour and Khoshgoftarmanesh, 2014). Iron supply treatment is found to be modulated the gene expression of anthocyanin biosynthesis in coloured grape (Shi et al., 2016). Improvement in anthocyanin content with the application of $\mathrm{Zn}+\mathrm{Fe}$ is also reported in strawberry (Kumar et al. 2010). 
Table 3: Effect of foliar application of micronutrients on physico-chemical properties of strawberry cv. Winter Dawn

\begin{tabular}{|l|c|c|c|c|c|c|c|}
\hline Treatments & $\begin{array}{c}\text { Fruit } \\
\text { firmness } \\
\left(\mathrm{kg} \mathrm{cm}^{2}\right)\end{array}$ & $\begin{array}{c}\text { TSS } \\
\left({ }^{\circ} \mathrm{B}\right)\end{array}$ & Acidity (\%) & $\begin{array}{c}\text { Ascorbic } \\
\text { acid } \\
(\mathrm{mg} / 100 \mathrm{~g})\end{array}$ & $\begin{array}{c}\text { Reducing } \\
\text { sugar }(\%)\end{array}$ & $\begin{array}{c}\text { Total } \\
\text { sugar } \\
(\%)\end{array}$ & $\begin{array}{c}\text { Anthocyanin } \\
\text { content } \\
(\mathrm{mg} / 100 \mathrm{~g})\end{array}$ \\
\hline $\mathrm{T}_{1}: 0.2 \% \mathrm{ZnSO}_{4}, 7 \mathrm{H}_{2} \mathrm{O}$ & 0.29 & 8.00 & 0.69 & 74.05 & 4.35 & 8.22 & 33.13 \\
$\mathrm{~T}_{2}: 0.4 \% \mathrm{ZnSO}_{4}, 7 \mathrm{H}_{2} \mathrm{O}$ & 0.46 & 8.21 & 0.70 & 85.24 & 4.66 & 8.54 & 36.20 \\
$\mathrm{~T}_{3}: 0.2 \% \mathrm{FeSO}_{4}, 7 \mathrm{H}_{2} \mathrm{O}$ & 0.32 & 8.15 & 0.73 & 74.33 & 4.44 & 8.21 & 34.00 \\
$\mathrm{~T}_{4}: 0.4 \% \mathrm{FeSO}_{4}, 7 \mathrm{H}_{2} \mathrm{O}$ & 0.34 & 8.33 & 0.71 & 82.28 & 4.54 & 8.58 & 35.03 \\
$\mathrm{~T}_{5}: \mathrm{T}_{1}+\mathrm{T}_{3}$ & 0.34 & 8.51 & 0.72 & 85.38 & 4.69 & 8.77 & 36.45 \\
$\mathrm{~T}_{6}: \mathrm{T}_{1}+\mathrm{T}_{4}$ & 0.40 & 8.44 & 0.68 & 88.45 & 4.72 & 8.96 & 36.83 \\
$\mathrm{~T}_{7}: \mathrm{T}_{2}+\mathrm{T}_{3}$ & 0.49 & 8.62 & 0.65 & 91.50 & 5.13 & 9.52 & 40.86 \\
$\mathrm{~T}_{8}: \mathrm{T}_{2}+\mathrm{T}_{4}$ & 0.52 & 8.75 & 0.64 & 94.16 & 5.14 & 9.55 & 41.00 \\
$\mathrm{~T}_{9}:$ Control (No spray) & 0.22 & 7.48 & 0.72 & 72.00 & 4.32 & 8.15 & 32.76 \\
$P \leq 0.05$ & $\mathrm{NS}$ & 0.61 & $\mathrm{NS}$ & 7.37 & 0.40 & 0.70 & 4.04 \\
\hline
\end{tabular}

This study aimed to improve the fruit yield and quality of strawberry with the foliar application of two most commonly used micronutrients (zinc and iron) in fruit orcharding. The outcome of the experiment suggested that the growth and yield of strawberry plant could be improved through foliar spraying of $0.4 \%$

\section{REFERENCES}

Afrin, S., Gasparrini, M., Forbes-Hernandez, T.Y., Reboredo-Rodriguez, P., Mezzetti, B., Varela-López, A., Giampieri, F. and Battino, M. (2016) Promising health benefits of the strawberry: a focus on clinical studies.Journal of Agricultural and Food Chemistry 64(22): 4435-4449.

AOAC (1980) Official Method of Analysis. Association of Official Analytical Chemist, AOAC, Benjaminn Franklin Station, Washinton DC.

Bakshi, P.; Jasroyia, A.; Sharma, A.; Rai, P.K.; Wali, V.K. and Kumar, R. (2013) Pre-harvest application of iron and zinc influences growth, yield, quality and runner production of strawberry (Fragariax ananassaDuch) cv. Chandler. Indian Journal of Agricultural Sciences 83(6): 92-98.

Basu, A., Nguyen, A., Betts, N.M. and Lyons, T.J. (2014) Strawberry as a functional food: an evidence-based review. Critical Reviews in Food Science and Nutrition 54(6):790-806.

Kumar, S., Yadav, M. and Singh, G.K. (2010) Effect of iron and zinc on fruit yield and quality of strawberry (Fragaria ananassa).Indian Journal of Agricultural Science 80(2): 171-173.

Mirzapour, M.H. and Khoshgoftarmanesh, A.H. (2013) Effect of soil and foliar application of
$\mathrm{ZnSO}_{4}, 7 \mathrm{H}_{2} \mathrm{O}+0.2 \% \mathrm{FeSO}_{4}, 7 \mathrm{H}_{2} \mathrm{O}$ at 30,60 and 75DAP. However, improvement in strawberry fruit quality was observed with the foliar application of $0.4 \% \mathrm{ZnSO}_{4}, 7 \mathrm{H} 2 \mathrm{O}+0.4 \%$ $\mathrm{FeSO}_{4}, 7 \mathrm{H}_{2} \mathrm{O}$ sprayed at the same days intervals.

iron and zinc on quantitative and qualitative yield of pomegranate. Journal of Plant Nutrition 36(1):55-66.

Rathod, K.D., Ahlawat, T.R., Kumar, S., Sarkar, M. and Chakraborty, B. (2021) Effect of plant growth regulators on growth, yield and quality of strawberry (Fragaria $x$ ananassa Duch.) cv. Winter Dawn under open field conditions of south Gujarat. Agricultural Science Digest 41(2): 329-333. doi:10.18805/ag.D-5240

Shanker, K., Misra, S., Topwal, M. and Singh, V.K. (2019) A research review on use of micronutrient in fruit crops. International Journal of Current Microbiology and Applied Sciences 8 (8): 3014-3025.

Snedecor, G.W. and Cochran, W.G. (1967) Statistical methods ( ${ }^{\text {th }}$ Edn.)Oxford and IBH Publ. Co., New Delhi, India 593.

Song, Z., Ma, R., Zhang, B., Guo, S., Yu, M. and Korir, N.K. (2016) Differential expression of iron-sulfur cluster biosynthesis genes during peach fruit development and ripening, and their response to iron compound spraying. Scientia Horticulturae 207: 73-81.

Srivastava, R.P. and Kumar S. (2001) Fruit and vegetable preservation: principles and practices. CBS Publisher and Distributors Pvt. Ltd. New Delhi-110002 India. 